\title{
The Analysis of the Determinant Factor of Premature Rupture of Membrane on the Inpartu Mother in the IRNA 1 RSU Moh. Noer Pamekasan
}

\author{
Lailatul Hafidah ${ }^{1}$ \\ ${ }^{1}$ Magister of Health Study \\ Program of STIKes Surya Mitra \\ Husada Kediri \\ Email: \\ lelyakper@gmail.com
}

Received : October 4, 2018

Accepted : October 6, 2018

Published : November 30, 2018

\begin{abstract}
Early Rupture of membranes is a rupture of the membranes when inpartu with opening at primipara less than $3 \mathrm{~cm}$ and in multiparas less than $5 \mathrm{~cm}$, without depending on gestational age. Some factors which are suspected to be the cause of premature rupture of membranes are parity, history of KPD, sexual status and anemia. The purpose of this study is to analyze the determinant factor of premature rupture of membranes on the inpartu mother in the Inpatient Installation Room 1 RSU Moh. Noer Pamekasan. The type of research is quantitative research with cross sectional research design. The study was conducted on January 30 to March 15, 2018 in the Inpatient Installation Room 1 RSU Moh. Noer Pamekasan. The sample is 59 respondents taken with simple random sampling. The independent variables are parity, history of premature rupture of membranes, sexual status and anemia. Dependent variable is premature rupture of membranes. The data was analyzed by using logistic regression test with $\mathrm{p}=0,05$. The results showed that the variable $\mathrm{X} 1$ (parity) with $\mathrm{p}=0.037$; OR = 0,008 , variable $X 2$ (history of KPD) with $p=0,049$; $O R=23.736$ ), Variable X3 (sexual relationship status) with $\mathrm{p}=0,064$; OR = 19.770; Variable X4 (anemia) with $\mathrm{p}=0,628$; OR $=2,132$. So it can be concluded that the factors which affect $\mathrm{Y}$ (the incidence of premature rupture of membranes) is a parity factor and history of KPD and the most dominant factor is the parity with the effect of 0.008.The high parity or parity of grandemultipara and the history of KPD to the previous labor affects the occurrence of premature rupture of membranes in the Inpatient Installation Room 1 RSU Moh.Noer. So it is necessary to do health education about the factors which affect the occurrence of premature rupture of membranes to prevent premature rupture of membranes recurring at the next labor.
\end{abstract}

Keywords: Anemia, history of PRM, parity, premature rupture of membranes and sexual intercourse status

Copyright (C) 2018 STIKes Surya Mitra Husada All right reserved.

This is an open-acces article distributed under the terms of the Creative Commons Attribution-ShareAlike 4.0 International License.

\section{INTRODUCTION}

The incidence of rupture of membranes early in some areas is high, this is evidenced by the high rate of referral with cases of premature rupture of membranes by the village midwife to the hospital with more adequate health facilities. Based on Indonesia's health profile (2015) that Maternal Mortality Rate (AKI) is 305 / 100,000 live births. The factors causing maternal death are 40-60\% 
bleeding, preeclampsia $20-30 \%$, infection $20-30 \%$. The cause of infection is the incidence of premature rupture of membranes that are not immediately get treatment.

The purpose of this study is to analyze the determinant factors that affect the occurrence of premature rupture of membranes in the maternity mother in the Inpatient Room 1 RSU Moh. Noer. The specific purpose is to analyze the parity factor on the occurrence of premature rupture of membranes in the maternal mother; analyze the history of premature rupture of membranes to premature rupture of membranes in maternal mothers, analyze the status of sexual intercourse on premature rupture of membranes in maternal mothers, analyze the anemia factor on premature rupture of membranes in maternal mothers, analyze the most dominant factors affecting the occurrence of rupture of membranes early in the delivery mother in IRNA Room 1 RSU Moh. Noer.

\section{METHODS}

This research type is quantitative with cross sectional research design. The study was conducted on January 30-March 15, 2018 in Room IRNA 1 RSU Moh. Noer Pamekasan, sampling technique used simple random sampling and obtained a sample of 59 respondents. Independent variables are parity, history of premature rupture of membranes, sexual status and anemia. Dependent variable is premature rupture of membranes. Data were analyzed using logistic regression test with $\mathrm{p}$ $=0,05$.

The instrument used to measure the respondents had anemia measured using the secondary data observation instrument of the patient status, the measurement using the patient's Hemoglobin data from the results of the patient's investigation. Instrument Sexual status using quesioner type multiple choice. Early history of rupture membranes using a quesioner type of closseended dichotomy questions. The insrument used to assess parity uses a multiple choice type quesioner. For dependent variable use method of observation of secondary data from patient status.

\section{RESULTS}

1) Distribution of Respondent Characteristics based on parity

Table 4.1 distribution of characteristics based on parity

\begin{tabular}{clccc}
\hline No & & Parity & f & $\%$ \\
\hline 1. & Primipara & 15 & 25,4 \\
\hline 2. & Multipara & 16 & 27,1 \\
\hline 3. & Grandemultipara & 28 & 47,5 \\
\hline & Total & 59 & 100 \\
\hline
\end{tabular}

Primary data source 2018

Based on table 4.1 above is known ampir half of respondents with grandemultipara parity of 28 respondents $(47.5 \%)$.

2) Distribution of Respondent Characteristics based on history of premature rupture of membranes.

Table 4.2 Distribution of characteristics Based On The History of Premature Rupture of Membranes

\begin{tabular}{cccc}
\hline No & History of Premature Rupture of Membranes & $\mathrm{f}$ & $\%$ \\
\hline 1. & Have a history & 44 & 74,6 \\
\hline 2. & Have'nt a history & 15 & 25,4 \\
\hline & Total & 59 & 100 \\
\hline
\end{tabular}


Primary data source 2018

Based on table 4.2 above most respondents have a history of premature rupture membrane as many as 44 respondents $(74.6 \%)$.

3) Distribution of Respondent Characteristics based on history of sexual intercourse

Table 4.3 Distribution of characteristics based on history of sexual intercourse

\begin{tabular}{cccc}
\hline No & history of sexual intercourse & $\mathrm{f}$ & $\%$ \\
1. & Yes & 9 & 15,3 \\
2. & Not & 50 & 84,7 \\
& Total & 59 & 100 \\
\hline
\end{tabular}

Primary data source 2018

Based on table 4.3 above it is known that almost all respondents did not have sexual intercourse before premature rupture membrane as much as 50 respondents $(84,7 \%)$.

4) Distribution of Respondent Characteristics based on anemia

Table 4.4 distribution of characteristics based on anemia

\begin{tabular}{cccc}
\hline No & Anemia & f & $\%$ \\
\hline 1. & Not & 24 & 40,7 \\
\hline 2. & Low & 25 & 42,3 \\
\hline 3. & Moderat & 9 & 15,3 \\
\hline 4. & Weight & 1 & 1,7 \\
\hline & Total & 59 & 100 \\
\hline
\end{tabular}

Based on Table 4.4 above it is known that almost half of respondents have mild anemia as much as 25 respondents $(42.3 \%)$.

5) Distribution of Respondent Characteristics based on premature rupture of membranes

Table 4.5 Characteristic distribution based on premature rupture of membranes

\begin{tabular}{cccc}
\hline No & Premature rupture of membranes & f & $\%$ \\
\hline 1. & Have premature rupture of membranes & 49 & 83 \\
\hline 2. & Have not premature rupture of membranes & 10 & 17 \\
\hline & Total & 59 & 100 \\
\hline
\end{tabular}

Primary data source 2018

Based on Table 4.5 above it is known that almost all of respondents have premature rupture of membrane as much as 49 respondents $(83 \%)$. 
6) uji statistik secara multivariat dengan uji regresi logistic, dengan menggunakan aplikasi SPSS for windows versi 16.0. Hasil analisisnya adalah sebagai berikut:

Tabel 4.6 hasil uji statistik analisis faktor yang mempengaruhi kejadian ketuban pecah dini

\begin{tabular}{cccccccc}
\hline No & Variabel & B & S.E & Wald & df & Sig. & Exp(B) \\
\hline 1 & Paritas & 4.801 & 2.305 & 4.339 & 1 & .037 & .008 \\
\hline 2 & Riwayat KPD & 3.167 & 1.612 & 3.860 & 1 & .049 & 23.736 \\
\hline 3 & Status hubungan seksual & 2.984 & 1.614 & 3.418 & 1 & .064 & 19.770 \\
\hline 4 & anemia & .757 & 1.563 & .235 & 1 & .628 & 2.132 \\
\hline & Constant & .650 & 3.621 & .032 & 1 & .858 & 1.915 \\
\hline
\end{tabular}

$* \mathrm{p}<0,05$

Based on Table 4.6 above it is known obtained statistical test result using logistic regression of all variable indicate there are two variable factors that affect the occurrence of rupture of membrane early, because it has a p- value is smaller than the alpha value of parity variable and the history of premature rupture membrane, that most affect the incidence of premature rupture of membranes is a parity factor with the value of $p$ - value 0,037

\section{DISCUSSION}

\section{A. The effect of parity factor on the occurrence of premature rupture of membranes in the delivery mother in IRNA 1 RSU Moh. Noer}

Based on the results of research conducted in inpatient wards 1 RSU Moh. Noer Pamekasan from 59 respondents almost half of respondents who have grandemultipara parity also experienced membrane rupture early as 28 respondents $(47.5 \%)$. From result of logistic regression test known that $\mathrm{p}$-value value $=0,037$ with $\mathrm{OR}=0,008$ because value of $\mathrm{OR}<1$, then the chances of premature rupture of membranes in the mother with grandemultipara greater than 0.008 times compared with mothers with primipara parity. Because p-value $<0,05$, so $\mathrm{H} 1$ accepted and Ho rejected which means there is parity influence to the occurrence of premature rupture of membranes in the delivery mother in inpatient wards 1 RSU Moh. Noer.

The results of this study are in line with the results of previous research conducted by Ery Kartika Sari et al (2013) who examined parity and abnormalities with the incidence of PRM in Balongsari Puskesmas Surabaya. There is a relationship between parity and abnormality with the incidence of PRM. According to Mochtar Morgan (2009), that parity allows cervical damage during previous births. This is also reinforced by other theories which suggest that premature rupture of membranes will increase in maternal grandemultipara. In theory it is said that the membranes are not strong membrane as a result of the lack of connective tissue and vascularization that causes premature rupture of membranes (Lestari, 2013).

Maternal mortality in pregnant women and childbirth at risk ranges from under 20 years is $2-5$ times higher than maternal deaths that occur at the age of 20-30 years. Maternal deaths rebound after 35 years of age while at $<20$ years the reproductive organs in women have not been fully formed. At the age above 35 years of pregnancy is usually followed by degenerative diseases such as high blood pressure or deabetes mellitus. As we get older, the risk of degenerative diseases is more prevalent than those of younger age. The degenerative disease directly or indirectly affects the process of pregnancy and childbirth in both mother and baby. Delaying gestational age at too young age such as following a family planning program to reach reproductive age and not delaying marriage and pregnancy in old age is one of the attempts to reduce complications in pregnancy and childbirth so as to reduce 
maternal mortality. In addition, communication, information and good education should be given to pregnant women appropriately. Information to be submitted to pregnant women is associated with high-risk parity and age in pregnant women, where parity with grandemultiara has a greater risk of premature rupture of membranes than mothers with primiparity parity because in grandemultipara suffered cervical damage during previous births. The more frequent the mother gives birth the more often the cervix is damaged, thus increasing the risk of premature rupture of membranes.

\section{B. The influence of history of premature rupture of membranes on the occurrence of premature rupture of membranes in maternity in IRNA 1 RSU Moh. Noer}

Based on the results of research conducted in IRNA 1 RSU Moh. Noer Pamekasan from 59 respondents most respondents who have a history of premature rupture of membranes experience premature rupture of membranes as much as 42 respondents (71.2\%). From the results of logistic regression test note that the value of $p$-value $=0,049$ with $\mathrm{OR}=23.736$ this means that if the mother has a history of premature rupture of membranes, the chances for premature rupture of membranes in the next delivery of 23.736 times greater than mothers who do not have a history of premature rupture of membranes. Since the p-value $<0,05$, so $\mathrm{H} 1$ is accepted and Ho is rejected which means there is an effect of history of premature rupture of membranes on premature rupture of membranes in the delivery mother in IRNA 1 RSU Moh. Noer Pamekasan.

The results of this study are in line with the results of previous research conducted by Suriani Tahir et al (2012) which examines the determinants of premature rupture of membranes in RSUD Syekh Yusuf Gowa District. From the results of the research, the results of data analysis showed that the ratio of PRM experience in mothers whose work caused fatigue and duration of $>3$ hours / day was 3.6 times greater than working mothers were not tired. Mothers who had experienced PRM were 4.7 times greater than those who had never experienced PRM, maternally pregnant mothers at risk 3.0 times greater than those who did not get pregnant twins. According to Utomo's (2013) study, a previous incidence of premature rupture of membranes suggests that women who have given birth several times and experience premature rupture of membranes in previous pregnancies are believed to be at increased risk for premature rupture of membranes in subsequent pregnancies, this was stated by Cunningham et all (2012). Conditions that can interfere with maternal and fetal health in the womb may also increase the risk of birth with premature rupture of membranes.

Mothers with a history of premature rupture of membranes then the chances for an early rupture of membrane is higher than mothers who do not have a history of premature rupture of membranes in subsequent pregnancies, this happens because the decrease in collagen content in the membrane thus triggering premature rupture of membranes and preterm premature rupture of membranes, especially in high-risk patients.

\section{Influence on the status of sexual intercourse on premature rupture of membranes in the delivery mother in IRNA 1 RSU Moh. Noer}

Based on the results of research conducted in inpatient wards 1 RSU Moh. Noer Pamekasan from 59 respondents most of the respondents who did not have sexual intercourse but experienced premature rupture membrane as much as 43 respondents $(72,9 \%)$ in respondents in Installation of Inpatient 1 RSU Moh. Noer Pamekasan. From result of logistic regression test known that p-value value $=0,064$. Because $\mathrm{p}$-value value $>0,05$, so H1 is rejected and Ho accepted which means there is no influence of sex intercourse on the occurrence of premature rupture of membranes in the delivery mother in inpatient wards 1 RSU Moh. Noer Pamekasan.

The result of the research is in line with the research conducted by Tahir (2012) in RSUD Syekh Yusuf Gowa Regency to get the result that sexual intercourse is not a risk factor affecting PRM because of equality of proportion between case and control this is in accordance with the theory proposed by Irfan Hasuki (2011) that not all pregnant women should be limited in terms of frequency of Sexual intercourse, coital position, and deep penile penetration, this only applies to mothers with incompetent cervical problems, women with previous PRM history, placenta previa, history of abortion or preterm birth, history of vaginal bleeding and mothers with a history of sexually transmitted diseases. According to Winkjosastro (2002) that Sexual intercourse at the age of gestation 
will facilitate birth because at that time there is spasm of the uterine muscle, caused by men ejaculate and sperm into the vagina, where in the sperm there is prostaglandin, the hormone that can cause contraction and can cause uterine muscle spasm, although the concentration is not large enough to cause spasm.

Sexual intercourse while pregnant is still recommended for pregnant women in general provided they can control or control themselves not to contract. Frequency of sexual intercourse with frequency exceeding 3 times a week is better, the position of the husband should still be on top but not pressing the abdominal wall, penile penetration should still be deep but slowly or slowly, and ejaculation of sperm remain in the vagina but calm- just be calm and not too aggressive. Sexual intercourse is not recommended for pregnant women with a history of abortion, placenta previa, vaginal bleeding, history of premature births, incompetent cervix, and mothers with no history of premature rupture of membranes because having sex during the third trimester of pregnancy is believed to help speed up the birth process.

\section{The influence of anemia factor on the occurrence of premature rupture of membranes in the delivery mother in IRNA 1 RSU Moh. Noer}

Based on the results of research conducted in IRNA 1 RSU Moh. Noer Pamekasan from 59 respondents almost half of respondents who experienced anemia experienced premature rupture of membranes as many as 26 respondents (44.1\%) in respondents in Inpatient Installation 1 RSU Moh. Noer Pamekasan. From the result of logistic regression test, it is known that p-value value $=0,628$ because p-value value> 0,05 , so $\mathrm{H} 1$ is rejected and Ho accepted which means there is no effect of anemia on the occurrence of premature rupture of membranes in the maternity ward in IRNA 1 RSU Moh. Noer Pamekasan.

The results of this study are in line with research conducted by M. Irsam et al (2014) who examined the amount of parity and anemia as predictors factor of premature rupture of membranes similar to the results of this study which explains that parity most influence on the occurrence of PRM while anemia and fetal abnormalities not related to PRM incident. According to Elvina (2012) that anemia in pregnant women can cause many problems, including premature birth, LBW, and increase the risk of death in babies who are born, whereas in mothers with severe anemia can increase maternal mortality in the childbirth process.

Pregnant women with anemia cause immunity and the supply of nutrients to the fetus is reduced, low hemoglobin levels allow pregnant women to become infected easily. Lack of iron consumption found in red meat, liver, green beans and vegetables and vitamin $\mathrm{C}$ intake can cause mother anemia. In fact, the government has made efforts to reduce anemia by providing supplemental free blood tablets, pregnant women given tablets plus blood sebayak 90 tablets and should be taken during pregnancy, non-adherence to consume blood supplements and lack of knowledge of iron benefits to cause low numbers consumption of this tablet in pregnant women, many pregnant women who do not want to drink because there are complaints such as nausea. Pregnant women with anemia may affect the body's response to infection, thus affecting the strength of the collagen membrane and causing abnormalities of the collagen structure.

\section{E. The most dominant factors that affect the occurrence of premature rupture of membranes in the maternal mother in IRNA 1 RSU Moh. Noer}

Based on the result of statistical test of logistic regression got value on parity factor $p=0,037$; OR 0.008 and on the history of premature rupture of membranes $p=0.049$; OR $=23.736$. This implies that since the OR value is 1 , then parity is not a risk factor but is a protective factor against PRM. If the maternal mother has a grandemultipara parity then it should be more protect themselves so as not to happen membranes rupture early at the time of delivery.

The results of the study were in line with previous research conducted by Ni Luh Sumadi (2013) who examined the risk factors associated with premature rupture of membranes where the results showed that there was a relationship of parity and risk factors for infection with the incidence of premature rupture of membranes and the most dominant factor was Factor risk of infection. According to Nugroho, T. (2012) that premature rupture of membranes is rupture of the membranes 
when inpartu with opening at primipara less than $3 \mathrm{~cm}$ and in multiparas less than $5 \mathrm{~cm}$, regardless of gestational age. Early rupture of membranes is more common in term pregnancy compared with premature pregnancy. The cause of this PRM is not yet known for certain but most likely caused by the parity factor, and the abnormality of the location. Signs and symptoms of premature rupture of the pregnancy according to Maryunani (2013) is the passage of amniotic fluid seeping through the vagina, the smell of amniotic water odor and unlike the smell of ammonia, and if an infection occurs due to premature rupture of membranes it will show symptoms of fever, spots vaginal discharge, abdominal pain, fetal heart rate accelerate is a sign of infection that happen.

According to Cunningham (2012) that Parity is associated with an early rupture of membrane events in accordance with the theory that multiparous and grandemultipara parity conditions increase the risk of premature rupture of membranes. Multiparity causes intrinsic weakness of the uterus, due to cervical trauma in previous vaginal delivery. Multiparity causes increased uterine motility, abdominal hanging, and decreased cervical elasticity. The above, causing premature opening of the cervix results in PRM. The cervical arrangement of multigravida and grandemultipara more nerve fibers than the connective tissue. Damage to the cervical tissue allows the base muscles of the uterus to stretch.

The most dominant factor on the incidence of premature rupture of membranes is strongly influenced by parity. Pregnancy that is too frequent in grandemultipara affects the thickness of the membrane membrane becomes thinner so easily break prematurely. In primipara it should not be susceptible to PRM occurrence because it has never undergone childbirth nor has stretching on the uterus and also vascularization and connective tissue of the membranes is still strong. The more parity, the easier the infection of amniotic fluid due to damage to the cervical structure in previous labor. The number of children or parity $2-3$ is the safest parity in terms of maternal deaths. Parity 1 (primipara) compared with high parity (more than 5 or grandemultipara) has a maternal mortality or has a higher risk. Higher parity, higher maternal deaths due to maternal complications such as the occurrence of PRM. Although not a single factor causing premature rupture of membranes but parity factor is also believed to affect the occurrence of premature rupture of membranes, other things that can support the occurrence of premature rupture of membranes are infection of the genitalia which is characterized by vaginal discharge, stress (psychological burden) during pregnancy and other things exacerbate the condition of the mother and cause premature rupture of membranes.

\section{REFERENCES}

Istiqomah, A., \& Astria, Y. (2013). Hubungan Ketuban Pecah Dini dengan kejadian asfiksia di RS Nur Hidayah Bantul. Hal 1-7.

Budiarto, E. (2006). Biostatistik untuk kedokteran dan kesehatan massyarakat. Jakarta: EGC.

Chapman, V. (2015). Asuhan kebidanan persalinan dan kelahiran. Jakarta: Buku Kedokteran EGC.

Cooper, M. A. (2009). Buku Ajar Bidan Myles. Jakarta: EGC.

Cunningham, F. G. (2012). Obstetri Williams. Cetakan 23. Jakarta: EGC.

Dharma Kusuma. (2011). Metodologi penelitian keperawatan panduan melaksanakan dan menerapkan hasil penelitian. Jakarta: Trans Info Media.

Kartika Sari, E., \& Juaria, H. (2013). Paritas dan kelainan letak dengan kejadian ketuban pecah. Hal 1-9.

Farrer, H. (2007). Perawatan Maternitas. Jakarta: EGC.

Sun Ko, H. (2016). Placental histologic patterns and neonatal seizure, in preterm premature rupture of membrane.

Hasuki, I. (2011). Jangan berhubungan seks saat hamil. Jakarta: tabloid Nakita (20 Mei 2011). 
Kumalasari, I. (2015). Panduan praktek laboratorium klinik perawatan antenatal, intranatal, postnatal bayi baru lahir dan kontrasepsi. Jakarta: Salemba Medika.

Irsam, M. (2014). Jumlah Paritas dan Anemia sebagai Faktor Prediktor Kejadian Ketuban Pecah Dini RSUD Tugurejo Semarang pada tahun 2014. Hal. 1-8.

Armstrong, J., Donnelly, M., D. Post, M., J. Manco Johnson M., D. Winn M. D. V., \& Sébire, G. (2014). Inflammatory predictors of neurologic disability after preterm premature rupture of membranes.

B. Fortner, K., A. Grotegut, C., E. Ransom, C., C. Bentley, R., Feng L., Phillips Heine, R., C. Seed, P., \& P. Murtha, A. (2014). Bacteria Localization and Chorion Thinning among Preterm Premature Rupture of Membranes. Hal 1-10.

Handayani, L., Amelia, R., \& Sumarni, E. (2015). Hubungan pola seksual ibu Pecah dini di RSUD dr. H. Moch. Ansari Saleh Banjarmasin.

Titi, M. (2017). Hubungan Usia, Paritas Dengan Ketuban Pecah Dini Di Puskesmas Jagir Surabaya. Hal. 102108.

Manuaba, IBG. (2012). Ilmu Kebidanan, Penyakit Kandungan, dan KB. Jakarta: EGC.

Arif, M. (2010). Kapita Selekta Kedokteran edisi 4. Jakarta: Media Aesculapius.

Maryunani. (2013). Asuhan Kegawatdaruratan maternal dan neonatal. Jakarta: Trans Info Media.

Mitayani. (2009). Asuhan keperawatan maternitas. Jakarta: Salemba Medika.

Irsam, M., \& Kartika Dewi, A. (2014). Jumlah Paritas dan Anemia sebagai Faktor Prediktor Kejadian Ketuban Pecah Dini.

Ridwan, M., \& Herlina. (2013). Hubungan kehamilan ganda dan kelainan letak janin dengan kejadian Ketuban Pecah Dini di rsud demang sepulau raya. Hal 1-7.

Morgan, G., \& Hamilton, C. (2009). Obstetri dan Ginekologi: panduan paraktik (edisi 2). Jakarta: EGC.

Heidi, M. dkk. (2006). Kehamilan apa yang anda hadapi bulan per bulan. Edisi 3 Jakarta: Arca.

Nugroho, T. (2012). Patologi kebidanan. Yogyakarta: Nuha Medika.

Nursalam. (2016). Metodologi penelitian ilmu keperawatan - pendekatan praktis edisi 4. Jakarta: Salemba medika.

Prawirohardjo, S. (2009). Ilmu Kebidanan. Jakarta: P. T. Bina Pustaka.

Ningsih, S. (2016). Faktor-faktor yang berhubungan dengan Kejadian ketuban pecah dini di rumah sakit umum H. Abdul manan simatupang tahun 2016. 149-156.

Saifudin, A. B. (2009). Buku Acuan Kesehatan Maternal Neonatal. Jakarta: PT. Yayasan Sarwono Prawirohardjo.

Constance, S. (2009). Kondisi Ginekologis dan pertimbangan kehamilan serta kontrasepsi dalam buku saku kebidanan. Jakarta: EGC.

Aisyah, S. \& Oktarina, A. (2012). Perbedaan Kejadian Ketuban Pecah Dini Antara Primipara Dan Multipara. Hal 1-7.

Siyoto, S. (2015). Dasar Metodologi Penelitian. Sleman Yogyakarta: Literasi Media Publishing.

Sudarto. (2013). Anemia terhadap kejadian Ketuban Pecah Dini pada ibu bersalin di pontianak. Hal 1-5. 
Sukarni, I., \& Wahyu, P. (2013). Buku Ajar Keperawatan Maternitas. Yogyakarta: Nuha Medika.

Suhita, M. (2017). Metodologi penelitian kesehatan. Ponorogo: Forum Ilmiah Kesehatan.

Ni Luh, S. (2013). Faktor risiko yang berhubungan Dengan kejadian ketuban pecah dini IGD RSUP Sanglah Denpasar. Hal. 33-38.

Syahdan, S. (2015). Faktor-faktor yang berhubungan dengan kejadian Ketuban Pecah Dini (Ketuban Pecah Dini) pada ibu bersalin di Ruang Camar II RSUD Arifin Achmad. Hal 1-12.

Maharrani, T., \& Yunita Nugrahini, E. (2017). Hubungan usia, paritas dengan Ketuban Pecah Dini di puskesmas Jagir Surabaya. Hal. 1-8.

Suriani, T. (2012). faktor determinan ketuban pecah dini di RSUD Syekh Yusuf Kabupaten Gowa tahun 2012. Hal. 1-15.

Helen, V. (2008). Buku Ajar Asuhan Kebidanan. Jakarta: Buku Kedokteran EGC.

Wagiyo. (2016). Asuhan keperawatan antenatal, intranatal dan bayi baru lahir fisiologis dan patologis. Jakarta: Andi Offset.

Waryana. (2010). Gizi Reproduksi. Yogyakarta: Pustaka Rihama.

Winkjosastro. (2010). Buku panduan praktis pelayanan kesehatan maternall dan neonatal. Edisi 1 cet 12. Jakarta: Bina Pustaka. 